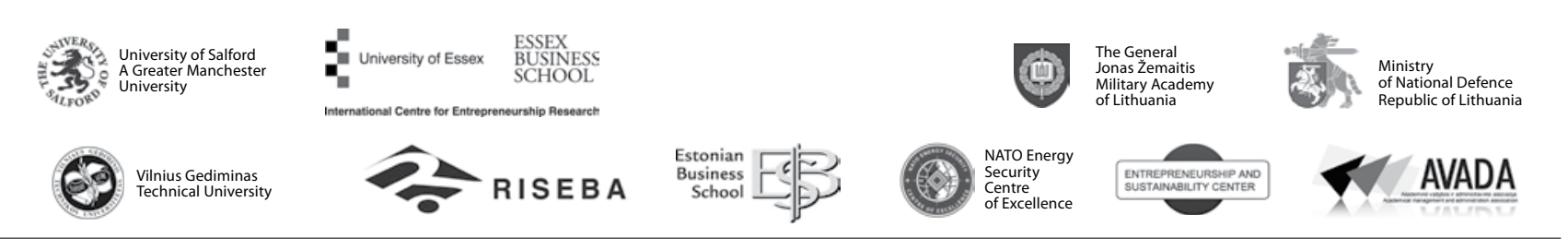

\author{
JOURNAL OF SECURITY AND SUSTAINABILITY ISSUES \\ ISSN 2029-7017 print/ISSN 2029-7025 online \\ 2017 June Volume 6 Number 4 \\ http://dx.doi.org/10.9770/jssi.2017.6.3(12)
}

\title{
THREATS AND CHALLENGES TO THE SECURITY AND STABILITY OF THE STATE OF LITHUANIA: HISTORICAL PERSPECTIVE*
}

\author{
Vytautas Jokubauskas \\ The Institute of Baltic Region History and Archaeology, Klaipeda University \\ Herkaus Manto Str. 84, LT-92294 Klaipéda, Lithuania \\ E-mail:pilsotas@yahoo.com
}

Received 10 January 2017; accepted 25 March 2017

\begin{abstract}
Ensuring security is one of the main functions of the state, therefore, in that area one has to deal with a wide range of threats and challenges. In the analysis of the changing security environment issues in the 21 st century, it is reasonable to look at historical events and to do appropriate case studies. Lithuania in the interwar period can be considered as a very valuable case in the context of the analysis of threats to national security. Over two decades, Lithuania acquired the experience of the conventional warfare, encountered analogues of little green men, and went through military coups, civil unrest, and the consequences of economic sanctions (economic warfare); it was exposed to external intelligence and agents of influence of other states operating underground who spread subversive rumours and distributed underground newspapers and leaflets. The present paper focuses on the range of those issues.
\end{abstract}

Keywords: Lithuania, economic sanctions,war refugees, military coup, civil unrest, uprising, non-state military formations, warfare, rumours.

Reference to this paper should be made as follows: Jokubauskas, V. 2017. Threats and challenges to the security and stability of the state of Lithuania: historical perspective, Journal of Security and Sustainability Issues 6(4): 673-689. http://doi.org/10.9770/jssi.2017.6.4(12)

JEL codes: R5

\section{Introduction}

As the security environment in the Baltic Sea Region, just like all over the world, keeps rapidly changing in the $21^{\text {st }}$ century, new challenges inspire one to view the issue from different perspectives. Despite the trends, patterns, and similarities, history is not a repeating process (historians study unique events), as there are always different conditions and actors (Carr, 1999). However, it still „happens“, i.e. certain parallels and similarities can be noticed. In that context, an apt observation is worth noting that history repeats „first as tragedy, then as farce" (Marksas, 1949). As stated by Robin George Collingwood (1946), in the course of development of the Western civilisation, people were thinking historically and have not stopped doing so, while historian John Tosh, when emphasising the significance of history, summed up:

„Historical difference lies at the heart of the discipline's claim to be socially relevant. As a memory-bank of what is unfamiliar or alien, history constitutes our most important cultural resource. It offers a means - imperfect but indispensable - of entering into the kind of experience that is simply not possible in our own lives. Our sense of the heights to which human beings can attain, and the depths to which they may sink, the resourcefulness they may show in a crisis, the sensitivity they can show in responding to each other's needs - all these are

\footnotetext{
* The paper was prepared in the implementation of the project The Strategy of Indirect Approach: the Case of Interwar Lithuania (LIP-096/2016) of the Research Council of Lithuania-funded National Programme for Lithuanian Studies and Dissemination in 2016-2024
} 
nourished by knowing what has been thought and done in the very different contexts of the past. $<$... $>$ History reminds us that there is usually more than one way of interpreting a predicament or responding to a situation, and that the choices open to us are often more varied than we might have supposed" (Tosh, 2010).

In the study, for the analysis of the security and stability of the state, the modus operandi of a historical approach has been chosen: the range of threats for national security and stability will be revealed, based on the Lithuania's case study. Their impact on the society development and the (non)preservation of the statehood will be established. The study aims to verify the hypothesis that indirect actions experienced by states is a permanent phenomenon intended to affect, weaken, or even enslave them. The interwar Lithuania is a case study to be carried out in three sections. First, the military factor in the national security assurance context will be dealt with, second, the impact of the internal national crises on the state stability; and third, the significance of economic and social problems for the sustainable development of the society and the state.

In the context of historical studies, the extrapolation from national security - economics, energy, public satisfaction with the quality of life, public information (disinformation or propaganda), and other fields - in the context of the current issues of the $21^{\text {st }}$ century can both contribute to the understanding of the genesis of those phenomena, the opportunities of their application, and their impact and consequences, as well as to the identification of the impact and for the preventive measures against undesirable effects. Upon analysis and reconsideration of different historical experiences, it may seem that nothing new is happening on the plane of the state security and stability of the $21^{\text {st }}$ century, as we face the application of the old, if slightly forgotten, methods by means of the latest technologies. The targets, however, remain the same: human well-being and their minds. During the conventional warfare, human lives are also sought.

\section{The military factor}

In the interwar years, Lithuania faced with a wide range of military threats. In the years 1919-1920, Lithuanian Wars of Independence with the Soviet Russia, the West Russian Volunteer Army (Bermontians), and Poland took place. During the wars, Lithuanians twice met with military formations that de jure were not state armies, i.e. the Bermontians and Żeligowski‘s Mutiny (Polish: bunt Żeligowskiego, also żeligiada). In the first case, it was the Germany-, and in the second, Poland-coordinated military units, however, the countries, to avoid the political consequences, formally distanced themselves from those formations. The West Russian Volunteer Army was formally created from the First World War Russian Empire Army prisoners of war in Germany, however, actually the bulk of the forces were former soldiers of the German Army. Their prime objective was to overthrow the Government of Latvia, and afterwards of other Baltic states, and to bring them under Germany's sphere of influence. Part of the Polish Army under General Lucjan Żeligowski „,rose up“ and captured Vilnius, the historical capital of Lithuania (Lesčius, 2004); their aim was to restore Lithuania that would be in unionist relations with Poland, as in the times of the Polish-Lithuanian Commonwealth. In 1919, the Polish Military Organisation (Polish: Polska Organizacija Wojskowa, $P O W$ ) organised a military coup in Lithuania, seeking to take over the power and to incorporate Lithuania in the Poland-planned union, however, the state of Lithuania managed to track it down and to prevent.

The Bermontians failed to implement their plans, while the forces of General Żeligowski were accompanied by a partial success. In the first case, those were strangers from other countries who had no relations with the territory they were fighting in. Moreover, their marauding and murders caused great indignation, and eventually resistance, of the local population. Besides, the German armed forces could not directly support them. Żeligowski's case was different. Part of his army were locals, coming from the areas where they were fighting. In addition, part of the local population were of the pro-Polish disposition and supported them. However, the key factor leading to their partial success was the fact that the flanks of the said forces were covered by two corpses of the regular Polish army (one in the south, in the Suwalki region, and the other in the north-east, in the Daugavpils region). The indirect support did not allow the Lithuanian army to counterattack and to get Vilnius back, as it would have fallen into a "trap“ - there was a risk of encirclement (Rezmer, 2004). Besides, the Lithuanian Army risked to get involved in large-scale open hostilities with all the Polish Army, and not only with the part of it which purportedly claimed to have risen up and no longer subject to Poland. 
Lithuania lost its historical capital Vilnius and about $1 / 3$ of the territory recognised as its part by Soviet Russia under the treaty of 12 July 1920, however, the conflict with Poland was not resolved in the interwar period, and its political consequences are still felt in the $21^{\text {st }}$ century. In the occupied Vilnius Region, a quasi-state was founded: the Republic of Central Lithuania (Polish: Republika Litwy Srodkowej), which in 1922 de jure (as de facto it already was in its composition) was annexed to the Republic of Poland. However, a region of a frozen conflict formed where permanent exchange of fire took place and, before 1923, all along the demilitarised zone (about $500 \mathrm{~km}$ in length), a Lithuanian and Polish guerilla warfare was fought (Vareikis, 1999, 2004), in which regular military units of both states were sometimes involved.

The Lithuanian Army was permanently preparing for a eventual war with Poland. There were fears that Poland may suddenly and unexpectedly invade Lithuania (Lesčius, 2013). Still, the conflict also had an international and diplomatic context, and in the League of Nations, an active struggle of both parties was going on, which nearly ended in Lithuania's recognition as aggressor; in that case Poland would have been given the mandate to „to curb“ Lithuania by military measures (Vilkelis, 2006; Žalys, 2007). In that context, next to Germany, a very important role in ensuring the security of Lithuania was played by the USSR (Kasparavičius, 1996, 1999, 2011, 2012), however, none of the countries had had a commitment to provide military assistance in the case of a war with Poland. Both Germany and the USSR supported Lithuania in accordance with their own interests, which most frequently did not correlate with the long-term interests of Lithuania.

Lithuania's war with Poland transformed into a prolonged frozen conflict which failed to be regulated until 1939, when the state of Poland ceased to exist de facto. Lithuanians were chanting: we shall not relent without Vilnius, as they had lost not only one third of the territory recognised by international agreements (under the border agreement with Soviet Russia of 1920, Lithuania got the area of 88 thousand $\mathrm{km}^{2}$, while interwar Lithuania covered the area of just 56 thousand $\mathrm{km}^{2}$ ), but also its historical capital Vilnius. Of course, it is important to note that the greater part of the lost eastern and southern territories were not Lithuanian in an ethnic sense, as the Polish and Belarusian languages predominated there, and the cities, as well as the whole region, boasted numerous Jewish communities. The situation between 1923 and 1938 could be defined as a frozen conflict, with no hostilities taking place, although border guards used to exchange fire and would sometimes wound or kill one another. Lithuania closed the demarcation line (the official state border had not been determined) and cut off the trade relations.

In order to destroy the self-confidence of the soldiers in the Lithuanian army and to break their will to resist, rumours (or false information) were spread. They were named in the army order of 1935: „Lithuania is a small and weak creature that can in no way resist Germany, therefore, sooner or later it will have to go to Germany“", or „we (Lithuania - V.J.) shall do nothing against Germans“; the rumour spread that, as soon as the war began, all the soldiers were going to drop their arms and surrender to Germany, or even that soldiers served in the enemy army (Kariuomenès štabo aplinkraštis, 1935). As observed in the army, quite a few of private soldiers tended to „very and very pessimistically view the army as a force“: „what can we do", ,we shall be smashed" were repeated again and again". Such an opinion was believed to be unjustified, unacceptable, and very harmful, as when the soldier's self-confidence was destroyed, the very sense of the fight was questioned (Šidlauskas, 1938). The rumours of that kind became especially active after the capitulation of Czechoslovakia in 1938 and the defeat of Poland in 1939. Great military power of the Soviets was publicly commented upon by Col. Jonas Černius, Chief of the General Staff of the Lithuanian Army, in 1937, after his visit to the USSR. In 1939, at the time of the Winter War, the Lithuanian press wrote that the Soviet military power was much greater as compared to the Finnish and that breaking the resistance of the Finns was only a matter of time (Jokubauskas, 2014), ,since it was such a power that the resistance of Finland against it, to think humanly, was impossible. Whether the fight will last several weeks longer of shorter, is not of great importance“ (Bagdonas, 1940). Thus, the ideas of the great power of the large states and the allegedly inevitable defeat of the small countries were made public (and penetrated into the military press), even if it did not happen in the case of Finland. In 1940, in the face of the Soviet ultimatum and occupation, according to the then Minister of Agriculture Juozas Audenas, he remembered the destructions of the First World War and believed that the nation would go and fight, if called to arms, however: 
„in the total war with a hundredfold greater enemy, there is no hope of defending ourselves, and the consequences of such a war can be immeasurably terrible. For the defence of the nation or the state, if it is at all possible, more than half of the population can be sacrificed. But is the sacrifice worth making when it results in a clear and complete defeat and there is no hope of victory?" (Audenas, 1966).

In the interwar period, a phenomenon of spiritual warfare was analysed which can be considered as a prototype of the information warfare, just at a lower (the interwar potential) technological level:

„The concept of the spiritual warfare includes: a war between enemies by word of mouth spread by the radio, agents, and the anti-state element; the war of the press, the diplomatic competition, and the secret espionage fight. In short, the battlefield of the warfare will be people's spirits, the area of their minds and nerves. The warfare has no front lines or boundaries: it covers all the territory of the state and concerns each individual. A spiritual warfare between the states takes place almost without a break, even at a quiet time - and in the case of the relationship deterioration, in the moments of tension, or in anticipation of an armed conflict, it goes in full force and uses all the weapons with the aim of affecting the spirit of the opposite side and of breaking the will of the fighters. The moral weapon sometimes manages to achieve so much that the physical force has only to make use of the victory of the spiritual weapon: a spiritually knocked down enemy has just to be taken captive and their land has to be occupied $<\ldots>$ The performance of the secret enemy propaganda and of the intelligence will be more successful in the case of an ignorant land, a low culture, and uneducated people. An ignorant person who has no state-related idea and no patriotism is much easier to be persuaded, frightened, or seduced. The narrower the mind, the lower level of the spiritual culture, the poorer understanding of the state and national affairs $<\ldots>$, the more withdrawn into the narrow circle of personal affairs, in the daily routine, and in the material concerns an individual shall be. Such an individual will be more susceptible to hypnosis and more fearful, as he has no idea and no stimulus for resolution and courage. And the success in scaring, in provoking fear is the best victory of an enemy, because the one who lost courage and is shaking has already been defeated: it remains only to put shackles on his hands" (Šepetys, 1939).

The issue of rumours (false information, disinformation, or propaganda) in interwar Lithuania was aptly defined in the Karys weekly:

„Lithuania hears quite a lot of rumours, and that has been happening from the very first days of the building of Independence. And that is because it has always had and continues to have different enemies who do not like Lithuania's Independence or the freedom of the Lithuanian nation. $<\ldots>$. Throughout the years of our statehood, if one pays more attention to the spreading rumours, one feels who is the master and the distributors of those rumours. And one notices! As soon as our state has a conflict with some neighbour about defending its own rights, immediately a certain group, that have a special liking for that neighbour, start disturbing people's minds with self-produced rumours. This dishonourable craft is mainly undertaken by some people from the ethnic minorities of Lithuania. $<\ldots>$ Remember that the rumour is spread by our enemies who wish to disturb our mood and to weaken our will and determination $<\ldots>$ The rumours are not only to undermine our nerves, but also to set us aginst friendly neighbours“ (Širvys, 1940). „In the fight against evil rumours, foreign state agents and their subversive activity, the humiliation of the power and the state authority, every conscious Lithuanian is invited to be active and thus contribute to the independence strengthening task" (Pirmasis karinès, 1940).

Thus, on the one hand, Lithuania, all the society, and its armed forces in the interwar years were faced with verbal attacks against the state, the political regime, the armed forces, and their ability to defend the country. On the other hand, the threats were identified, they were reflected upon in the press and in secret circulars intended for the army. A range of counter-measures was named: public education, observation of the environment, and the response to the distributors of rumours and disinformation in order to prevent their destructive activity. 


\section{Internal tensions}

A most frequently remembered and scientist-analysed case was the successful military coup of 17 December 1926, when the power was seized by the Christian Democrats and the Nationalists. Antanas Smetona became President, and Augustinas Voldemaras, Prime Minister; they quickly removed the Christian Democrats from power, and ultimately Voldemaras was also made to resign. Thus, Smetona got established in power, and his brother-in-law Juozas Tubelis became Prime Minister. That was when the saying „the land of brothers-in-law“ spread. An attempt was made to compensate for a lack of democracy through different public organisations, which acquired a wide scale, however, the opposition to the Nationalist political regime remained (Tamošaitis and Svarauskas, 2014). Therefore, the state experienced more than one attempt to seize power by a military coup. The failed Taurage uprising in 1927 and an unsuccessful military coup in 1934 were the best known cases. The army played an important role in the political life of the country (Vaičenonis, 2004), where the martial law was introduced and military censorship was in force (Kuodys, 2009).

However, even more problems were caused by the permanent threat of an uprising in the Klaipeda Region. From the geopolitical viewpoint, through Klaipeda Lithuania had access to the sea and became a maritime state; moreover, it could perform important functions of a buffer and a mediator between the mainland and marine routes (similarly to Antwerp in Belgium or to Rotterdam in the Netherlands) (Laurinavičius, 2010). On the other hand, the internal political situation in the Klaipeda Region and the local people's views on the Republic of Lithuania complicated the possible military defence prospects in that coastal area. In 1923, when after an improvised uprising the Klaipeda Region was annexed to Lithuania (Vareikis, 1995 and 2009), the local population was not very optimistic about the state of Lithuania. Before the First World War, in 1910, the people in the region whose native language was only Lithuanian accounted for 47,53\% (Vileišis, 1935), while during the population census in 1925, 26,56 \% reported they were Lithuanians, 24,24\%, Memellanders, and 45,28 \%, Germans. The emergence of a new group raised an issue of the causes of changes in the population identity and opened up possibilities for interpretations: since Germans accounted for $69,5 \%$, or Lithuanians for $51 \%$, of the population in the region they could thus justify their greater rights to the territory (Safronovas, 2010). However, pro-Lithuanian dispositions, or rather their nulity, were disclosed by the results of the election to the Seimelis (Landtag) of the Klaipeda Region, when the lists of Lithuanians would never get more than 5 places out of 29 (Žalys, 1993), thus, German parties predominated and always got over $80 \%$ of the votes (Žostautaite, 1992). Prussian Lithuanians in the Klaipeda Region and Lithuanians in Lithuania Major were linked by the language, while the culture and religion were the separating dimensions. No less imporatant was the fact that those two Lithuanian-speaking communities did not share a tangible common past that the community members were aware of. Therefore, defending the region whose population did not even desire to be „defended" was a hardly feasible mission for the Lithuanian Army (Žalys, 1993).

Incidents between the Lithuanian government and its military forces and the local population started as early as in 1923, and on April 6 to 11, one of the most unpleasant incidents of the 20 s of the $20^{\text {th }}$ century took place in Klaipeda: the strike of the local population (Žalys, 1993). On April 8, a crowd of about 9,000 people gathered in a Klaipeda suburb, and the Lithuanian armed forces were sent to disperse them: radically-minded people shouted at Lithuanian soldiers: „Szameiten, raus!“ Another outstanding case in the interwar period when the army had to calm the anti-state minded civilian crowds was known in the recovered Vilnius in the autumn of 1939, when the Lithuanian army was faced with the unrest and pogroms of the Polish-minded population (Žepkaite, 1990). On 2 August 1924, the Lithuanian Armed Forces Staff sent a telegram to inform Lt.Col. Petras Genys, Commander of the $7^{\text {th }}$ Infantry Regiment, about a planned assault on his regiment. The Regiment Commander reported that the local residents planned to rise up on the night from August 4 to 5 and first of all attack the Klaipeda barracks. When the meeting place of the heads of the uprising was found out, on the night of August 2, 11 of them were arrested with evidence. The press wrote that the rebels (about 400 men under the leadership of the former German Army Feldwebel Friedrich Blumenau) had planned to attack the barracks in Klaipeda at about 1 or 2 a.m. On 4 August 1924, the Lithuanian Armed Forces Staff informed the Commander of the $3^{\text {rd }}$ Military District that an uprising of the local population was again expected on August 23-25. In the late 1924, the Lithuanian Armed Forces Staff again informed the Commander of the $7^{\text {th }}$ Infantry Regiment that 
during Christmas local Germans or Communists may again try to organise ,a putsch“. On December 30, the Commander of the Regiment reported that, in accordance with the possessed information, at night Germans were planning to attack the Šilute Garrison that had already prepared to fend off the attack. The Armed Forces Staff immediately ordered the $5^{\text {th }}$ Infantry Regiment to be prepared to leave Kaunas for Klaipeda, and a plan of their transfer was prepared. However, the next day, Lt. Col. Genys informed that „nothing happened“. One of the threats in the Klaipeda Region named by the Lithuanian Armed Forces Staff was an uprising of the separatistically-minded local population, therefore, on 15 March 1927, a plan for the uprising suppression was made. In 1931, the Staff issued an additional order for the army to start suppressing unrest in case the police and the Riflemen were unable to do that. Provided the communication with the military authorities were lost, the army was ordered to act at its own discretion. Communists who could organise unrest were also considered as a threat, and a plan of the Klaipeda City defence was prepared (Jokubauskas, 2016). Most of the Germans from the Klaipeda Region, who were guided by a slogan „The Nemunas is our river, but not our border“ believed the new situation to be temporary. For them, the existence of Klaipeda in the sovereignty of Lithuania seemed to be the greatest historical injustice (Žalys, 1993).

In 1934, the Neumann-Sass trial started, when several hundred inhabitants of the Klaipeda Region were detained, and secret weapon and ammunition warehouses were confiscated (Jokubavičienè, 2012). The separatist structure was incriminated in an intention to organise an armed uprising and to annex the region to Germany. After the trial that caused an international interest, 87 people were sentenced, 4 of them to death. Germany's response was harsh, and from the very beginning of the Neumann-Sass trial, attacks against Lithuania started, warning the public that Lithuanian with the assistance of France may even attempt to occupy East Prussia. Following the verdict, protest demonstrations in different cities were held. On 12-22 March 1935, on the border with Lithuania, Germany drew up the troops and held maneuvers, attended by Luftwaffe Reichsmarschall Hermann Göring (in the interwar period, the method of the military force demonstration on the border area was applied both by Poland and also by the USSR in 1940 when pressing to accept the ultimatum. On the border with Lithuania, it concentrated 220,000 soldiers, and altogether in three military districts against the Baltic countries, the Soviets had 542,000 soldiers (Мельтюхов, 2014), thus occupying Lithuania without an armed resistance). German military and civilian aircraft were flying over Lithuania with the aim of air reconnaissance. Over the period from 2 June 1934 to 18 February 1936, the Lithuanian airspace was violated at least 26 times. Simultaneously Germany used diplomatic measures, and over the years 1934 to 1935, it sent 17 notes to Lithuania. After experiencing the pressure of Germany and failing to get support from the great powers, Lithuania started retreating. Amnesties of the convicted followed. In the middle of 1938, not a single convict of the case was imprisoned, and not a single death sentence was carried out (Žostautaitè, 1992).

In 1938, i.e. 15 years after the annexation of the Klaipeda Region and when preparing for the commemoration of the $20^{\text {th }}$ anniversary of Lithuania's Independence, the head of the Klaipeda Garrison stated:

„The Klaipeda and Macikai Garrisons are stationed in very unfavourable conditions with regard to the coexistence with the local community. Part of the community is Germanised and watch the troops with hatred, which prevents the soldiers' communication with them. That part of the community lives in isolation from the troops and culturally has nothing in common with them. $<\ldots>$ The Lithuanian community in the neighbourhood of the German segment that the soldiers ought to culturally communicate with is financially poor. They enjoy a small number of cultural entertainments“ (Ažubalis, A. et al., 2007).

On 4 December 1938, in an incident related to the exchange of greetings, three individuals killed a 19-year-old Lithuanian Benediktas Jonušis with billiard cues. The young man died, because he refused to use the German way of greeting - Heil Hitler - and either hit or pushed another person who responded to his ,good evening“ by heil. In the late 1938, Rifleman Jonas Martinaitis informed that he had been stopped by a stranger and demanded to greet the latter with Heil Hitler by means of threats; he asked for instructions how to behave in such cases. Another candidate to Riflemen Jonas Kočinas from the Kavoliai Platoon was similarly stopped by a stranger and threatened with a weapon to greet him Heil Hitler, however, Kočinas took the weapon away from the attacker and brought it to the Platoon Commander. The incidents of that nature led to the situation when on 20 January 1939, on the eve of withdrawal from Klaipeda, the troops were directed by Brig.Gen. Stasys 
Raštikis, the Commander of the Lithuanian Armed Forces, to accept the greeting of Klaipedians by raising an arm and saying Heil! as a local custom and, when dressed in a uniform, to respond in compliance with the statute, and when dressed in civilian clothes, either in a way accepted in Lithuania Major or in compliance with the Klaipedian custom (Jokubauskas, 2013). Thus, even the military structures of Lithuania capitulated to the Nazis, and the autonomic Klaipeda Region gradually turned into a „National-Socialist island“ where the positions of Lithuania weakened (Vareikis, 2009a).

Those were just examples to demonstrate the tension in the Region. The epilogue followed in 1939, when Germany presented an ultimatum and demanded that Lithuania gave up the Klaipeda Region as historically German. The daily Vakarai on 19 March 1939 noted that tailors in Klaipeda were extremely busy making new Klaipeda Region and Germany flags with swastikas: one of them, together with his apprentice, made as many as 250 flags overnight. The newspaper stated that on that day ,there are many more flags with swastikas in the streets. The city is boasting green-white-red and German flags“ (Klaipedos nuotaikos, 1939).

Germany occupied the Klaipeda Region in March 1939 with the military units, stationed in East Prussia, and the navy (Vokietijos karine veikla, 1940). It prepared for the occupation of the Klaipeda Region very carefully. Adolf Hitler ordered Wehrmacht to be prepared for the occupation of the Region as early as in October 1938. In Königsberg, the headquarters were set up to take care of the annexation of the Klaipeda Region, and the meetings of Ernst Neumann and politicians of the Reich took place there. The Klaipeda SA (Germ. Sturmabteilung) storm troopers were trained there, and military instructors were travelling to the Region from East Prussia (Meindl, 2007). As the Lithuanian Army were urgently evacuating, and some of the institutions got trapped, the control of the region and the city was taken over by the SA troops. The barracks were besieged by crowds of the local people, who broke into the barracks territory flinging insults and threats and had to be driven off. Adolf Hitler arrived at the city, already controlled by groups of the local separatists, with a flotilla of 43 vessels and 30 military aircraft for a short visit: to make a speech from the theatre balcony. An agreement was imposed upon and dictated to Lithuania, while the great powers (France, Great Britain, Japan, and Italy were guarantors of the Klaipeda Region status in Lithuania), in order not to provoke Germany (or even acting already as its allies), kept quiet and did nothing to stop the aggression.

In the years 1935-1937, Lithuania was shaken by the farmer strike in the Suvalkija Region. The strike was launched due to a number of causes: a lack of democracy, restrictions of civil rights, and mainly by economic recession. The most notable centres of the farmers' unrest were the counties of Marijampole, Vilkaviškis, Šakiai, Seinai, Alytus, Trakai, and Raseiniai. The strike did not directly spread to other places of Lithuania, however, it had supporters all over the country. Three stages of the strike could be identified that differed in their intensity, forms of the struggle, and the organisational character. Stage 1 started at the end of May in 1935, when the movement just began to be organised, and lasted until mid-December of the same year. The main goal of the farmers' unrest was to demand the improvement of the economic situation, and it was pursued by boycotting towns and not supplying them with agricultural produce. Political requirements were also formulated: to organise national elections. The forms of the struggle typical of that stage included propaganda through leaflets, destruction of telephone poles, forced closing of dairies, threats, arson, and shooting at those who refused to support farmers or the representatives of the local governments. The first stage of the strike stood out by massive pickets of farmers on the roads, demonstrations or meetings, and armed clashes with the police. Stage 2 included the late 1935 and the August of 1936. It was less intense, and the character of the struggle changed: no more mass meetings were held, and terrorist actions were more popular than in Stage 1(such as destruction of telephone and telegraph wires, fires, and shooting at people who refused to support strikes). The movement became more conspirational and secret. Stage 3 that started in the autumn of 1936 was characterised with weak resistance manifestations. It ended in the autumn of 1937. During that period, only the former strikers undertook the organisation of new strikes, kept in touch with the political opposition, and looked for the ways to unite, however, their attempts were unsuccesful.

The Lithuanian press of that time, controlled by the power, offered three versions: the first one of the strike being fuelled by Germany, the second, by Communists, and the third, by the opposition parties (Kuodys, 2013). True, 
the traces of those groups of interest could be detected, however, they neither initiated the unrest nor were very popular with the farmers who went on strike: they just tried to take advantage of the situation and to escalate the tense situation in Lithuania even more. During the farmer strike, in many places of the Užnemune (the area on other side of the Nemunas), the leaflets of different content were secretly distributed (put up in public places, etc.). They were prepared and distributed by the members of the so-called „farmers“ unities“" (at the beginning of the strike), of the Lithuanian Communist Party, and the Iron Wolf organisation. In some cases, the members of the Lithuanian Peasant Nationalist Party and the Lithuanian Youth Union also participated in the production and /or the distribution of the leaflets. Even if the style and rhetoric of different leaflets varied, they all aimed to incite people's dissatisfaction with the then government. The leaflets spoke out against the then nationalist regime with President Antanas Smetona and Prime Minister Juozas Tubelis in the forefront. In most of the leaflets, farmers were encouraged to disobey the government, not to pay taxes or loans to banks, and not to serve in governmental jobs (as elders of villages or heads of rural administrative districts), etc. Part of the leaflets questioned the legitimacy of the government (Balkus, 2013). The government took advantage of the martial law to suppress not only the opposition, but also the farmers' strikes. For their direct suppression, the police and military commandants were called, assisted by Riflemen and the state security agents (Černevičiūte, 2013). In 1935-1936, military commandants punished 882 strike participants; 456 of them were taken to courts. For terrorist acts, 5 farmers were sentenced to death. Another four were shot dead in the clashes with the police. During the riot, 5 peasants and 3 policemen were wounded (Truska, 1996). In the $30 \mathrm{~s}$ of the $20^{\text {th }}$ century, all Lithuania was like a powder keg that could blow up at any time. However, one of the demands of the strike participants - to organise the Seimas (Parliament) elections - was partially implemented (Blažytė-Baužienė; Tamošaitis; Truska, 2009), even though a democratic character of the 4th elections to the Seimas was questionable.

Next to the above discussed strikes, uprising, and unrest that destabilised the state of Lithuania from within in the interwar period, one could also note the fact that part of the cultural elite and of the general public were affected by socialism and had leftist inclinations (Tamošaitis, 2010). The underground Communist Party was active even in the army; on the Comintern resolution, it was instructed to expand its activities in the army and to increase its influence there (Kariuomenès štabo, 1935). In the army, just like in all the society, pro-German and pro-Polish forces were very active. In Lithuania, the underground press of various types, leaflets, and espionage were widespread (Ir taikos, 1937-1940). In 1935, a secret circular of the Armed Forces Staff commented on the operation of the neighbouring countries in Lithuania:

„Their favourite method of work is to sow misunderstanding and cause distrust among Lithuanians. They would like to cause turmoil inside Lithuania and thus weaken our resistance at the international level, and simultaneously to mask their aspirations with regard to Lithuania“" (Kariuomenès štabo 1935).

The USSR and German Representative Offices in Kaunas and their Consulates in Klaipeda were implementing the interests of those states in Lithuania and supporting the anti-state, underground forces. The intelligence, agents of interest, or convinced Communists or National Socialists both collected information about the Lithuanian armed forces and waited, or occasionally sought, changes in the political regime or even the statehood status in part (the Klaipeda Region) or in the whole of Lithuania.

\section{The economic factor}

It has to be noted that due to the above-discussed protracted frozen conflict with Poland, the administrative line (border) between Lithuania and Poland was closed, and therefore the economic relations were minimal. As a result, the port of Klaipeda was strongly affected, as the trade of rafting by the Nemunas River from the forests of the former Province of Vilnius that had boomed before the First World War, as well as the export of the timber processed in Klaipeda, completely stopped (Žukas, 2010). Therefore, the port of Klaipeda had to reorient itself and from the raw timber export specialisation to transform into a wide-profile Lithuanian state port exporting great amounts of already processed products. Thus the port of Klaipeda ceased to be a transit port, and Lithuania economically closed about one third of its border and strongly increased its dependence on Germany (transit to the West via it and the trade). Lithuanian did not experience any economic difficulties due to all that as long as it had good relations with Germany which had a great demand for imported agricultural products and raw materials. 
As stated by Zenonas Norkus, in the mid-20s of the $20^{\text {th }}$ century, due to false economic estimations, the Lithuanian Government introduced strict austerity measures which led to the collapse of democracy through a military coup. Democracy failed in Lithuania not because of the left-wing excessive spending, but because of their excessive saving. It was the leftists who were saving, and the fruits of their savings policy were enjoyed by the enemies of democracy - the Nationalists who did not have any longer to take strict austerity measures Norkus, 2016). And it was in the years of the right-wing regime, in 1927, that the ,golden age“ started which lasted until the end of 1930. At that time, Lithuania's exports increased by $25,3 \%$, from $258,4 \mathrm{mln}$. Litas to $323,8 \mathrm{mln}$. Litas. However, the situation changed at the beginning of the $30 \mathrm{~s}$ of the $20^{\text {th }}$ century, when Lithuania was faced with a complex of economic problems:

1) a global economic crisis (the Great Depression;

2) economic sanctions of Germany;

3) currency devaluation in part of the countries of the world (trade partners);

4) the loss of the only commercial port and the industrial city of Klaipeda;

5) disruptions in the supply of raw materials and oil products (fuels);

6) admission and maintenance of war refugees, assistance to the population of the Vilnius Region in 1939-1940.

The Great Depression hit the Lithuanian economy, too (Butkus and Černiauskas, 2015), while the period of 1931 to 1935 could be seen as the time of hard challenges to Lithuanian economy and its financial system. Especially painful was the fall in the prices for agricultural products (Terleckas, 1992): in 1929, a centner of rye cost 22,8 Litas, while in 1935, only 5 Litas; a kilo of butter cost 6,6 and 1,7 Litas, respectively, etc. (Trus$\mathrm{ka}, 1996)$. In order to mitigate the consequences of the crisis, the Government reduced the prices for the rail, postal, and telegraph services, and the prices for some goods. Over the period of 1930 to 1935, from the state budget, farmers were paid 103,7 mln. Litas of premiums for the exported butter and pigs (Terleckas, 1992), while in 1930-1939, the total payments for the export of agricultural products (that presently would be called direct payments to agricultural producers) amounted to 172,7 mln. Litas (Vaskela, 1998). Thus,over a decade, the promotion of the export of agricultural products was asssigned the amount of funds from the state budget equal to that which had been planned for the military armaments in the implementation of a seven-year plan. All that made a negative impact on the national economy and the welfare of the population and led to a huge deflation when the domestic consumer price index significantly dropped. The lowest overall price index was in 1935, when it accounted for only 39,2 \% (in $1924=100 \%$ ) of the level ten years ago (Meškauskas et al., 1976). Moreover, Lithuania in the 30 s of the $20^{\text {th }}$ century did not devaluate its national currency, which reduced the prices in the domestic market and made export more difficult or reduced the benefits to be derived from the exports; the devaluation of the British pound of sterling hit especially hard. Such kind of the national monetary policy was useful only to receivers of regular income (civil servants) and moneylenders, but hit farmers and other small producers (Vaskela, 1998).

According to Norkus, „Lithuania in 1938, just like in 1913, remained the most backward Eastern European country", although in the period between 1924-1938, it surpassed its neighbours by an average annual economic growth rate $(4,3 \%)$. An average annual GDP growth in Finland during that period was 3,5\%, in Latvia, $3,2 \%$, and in Estonia, $1,9 \%$ (Norkus, 2015). However, in the 30 s of the $20^{\text {th }}$ century, Lithuania was faced with the problems of the global economic crisis and an embargo on Lithuanian imports imposed by Germany, which was even more exacerbated by the state's refusal to devaluate the national currency Litas, following the example of a number of other countries. Historian Liudas Truska wrote that in 1933, farmers' debt exceeded $460 \mathrm{mln}$ Litas (which was almost twice than an annual state budget), and the insolvent debtors' assets were described and sold at auction. In 1930, 1,050 farmers' auctions were held, in 1933, 2,908, and in 1934, 2,508. The prices of agricultural products fell 3 to 4 times, and of most of the basic industrial products, just by $20-30 \%$. For the crisis-crushed peasants, „medical treatment, a priest, a lawyer, public transport, and industrial goods“ were inaccessible. The decrease in the state budget revenues meant cutting down on expenses: schools were closed, the number of university students was reduced, etc. (Truska, 1996). 
To quote Norkus (2014):

„As the crisis struck the economy of Germany, Lithuania's main foreign trade partner, in order to defend its own farmers, the German Government introduced such high protective tariffs that they could not be overcome even by live animals and other raw agricultural products very cheaply exported to that country from Lithuania. Starting with 1931, the economic relations between Germany and Lithuania were further complicated by economic sanctions imposed on Lithuania by its great neighbour for its ,inappropriate“ policies in the Klaipeda Region, which turned into Lithuania's economic boycott in 1934-1935. Almost the only hope for Lithuanian exports was the market of Great Britain, however, it was too far away to export raw animal products there".

Lithuania used to export agricultural raw materials and products. The predominating goods were livestock and meat, butter, flax, and tow (Lietuva, 1990). In 1930, Lithuania exported to Germany 156, 000 pigs, in 1931, 109,000, and in 1933, only 21,800 (Vaskela, 1998). However, due to the Neumann-Sass trial in 1934 (the first case in Europe when criminal responsibility was applied by the court to National Socialists), Germany essentially closed its frontier to Lithuania's agricultural products. In 1933, Lithuania exported goods to Germany for 52,4677 mln. Litas, while in 1935, merely for 5,4352 mln. Litas, and only in 1938, the export (62,493 mln. Litas) reached the former level, i.e. from $32,75 \%$ fell to $3,57 \%$ and rose again to $26,8 \%$ (Table 1). Due to the trade embargo, Lithuania was faced with enormous overproduction. As stated in the memoirs of Vaclovas Šliogeris, former aide of the President of the Republic, in 1934:

„In Lithuania, the notorious ,geese eating“ began, when we had to consume the geese intended for the export by ourselves. To solve the problem of the geese overproduction, the Government ordered all the public sector staff to buy geese. The amount depended on the salary, and a special procedure was prepared and published to regulate the consumption of geese" (Aplinkraštis žąsų, 1934).

Lithuanian diplomats sent the message from Berlin to Kaunas to the effect that:

„,no good relations between Lithuania and Germany were possible until the Klaipeda Region was returned back to Germany" [Germany twice refused from the territory by signing international treaties: the Versailles Peace Treaty in 1919 and the Border Agreement with Lithuania in 1928, in accordance with which the Nemunas River served as a border - V.J.] (Lietuvos atstovybè, 1933).

In 1934, German Envoy in Kaunas Erich Zechlin warned that, unless an agreement was reached on the Klaipeda Region at the political level, Lithuania was to experience economic losses in relations with Germany. President Antanas Smetona responded by quoting the story about Esau from the Old Testament (Genesis, 25: 30-34), when

„Esau sold his birthright to Jacob for a bowl of lentil stew“ (Pro Memoria, 1934).

Lithuania's rights to Klaipeda were based on its belonging to the area of the Baltic tribes before the Orders' conquest and establishment there. Moreover, a substantial part of the population in the Klaipeda Region were ethnic Lithuanians - Prussian Lithuanians, differing from the rest of Lithuanians by the religion, culture, and several hundred years of political affiliation, and united with them by the origin and the language (for more information about Prussian Lithuanians, see: Pocytè, 2002). In addition, as mentioned above, Germany legally had twice refused from the territory in favour of the Entente and Lithuania.

However, the economic crisis and the sanctions imposed by Germany had a huge impact. The total value of the national export fell twice, and to Germany, 37 times. The revenues of the Lithuanian state budget, by prices of the current years, fell by a quarter from 1931 to 1934 . Before the crisis, the state budget was the largest in 1931 (335,3 mln. Litas), and recovered only in 1938 , when it amounted to $366,5 \mathrm{mln}$. One can calculate that, should the state budget in the period of 1932-1937 have stayed at the level of 1931, over the six years of the economic recession, another $350 \mathrm{mln}$ Litas would have been received by the budget (in 1932-1937, the state budget was $1662,4 \mathrm{mln}$. Litas, and should the annual revenue have stayed at the level of 1931, it would have been 2011,8 $\mathrm{mln}$. Litas (335,3 mln. Litas x 6 years)). A theoretical assumption follows that the global economic crisis and Germany's sanctions ,robbed“ Lithuania of two military rearmament programmes, as in the years 1935-1941 (a seven-year plan), $175 \mathrm{mln}$ Litas had been planned for the army modernisation ( $25 \mathrm{mln}$ Litas annually). 
The relationship between the export, the German sanctions, and the state budget can be revealed by means of the correlation coefficient calculation method, although the method does not reveal causality; moreover, the correlation may be random, as ,the coefficient of any size can be obtained also due to the random overlapping of variable values" (Norkus and Morkevičius, 2011). The value of correlation coefficients up to 0,36 is considered to be a weak correlation, from 0,36 to 0,67 , an average, 0,68 and more, a strong, and over 0,9 , a very strong correlation (Taylor, 1990). Based on that classification, the correlation between the total Lithuania's export and its export to Germany is very strong $(r=0,91)$, and the correlation between the export and the state budget is $r=0,71$, i.e. strong. An average correlation $(r=0,43)$ was established between the export volume to Germany (in mln Litas) and the Lithuanian State Budget (in mln Litas). The calculation was done by Microsoft Office Excel 2003 (function), in accordance with the formula:

$$
\operatorname{Correl}(X, Y)=\frac{\sum(x-\bar{x})(y-\bar{y})}{\sqrt{\sum(x-\bar{x}) \sum(x-\bar{x})^{2} \sum(y-\bar{y})^{2}}}
$$

Table 1. Lithuania's export and the state budget in the years 1930-1938

\begin{tabular}{|c|c|c|c|c|}
\hline \multirow{2}{*}{ Year } & \multicolumn{3}{|c|}{ Export, in mln. Litas } & \multirow{2}{*}{ State budget in mln. Litas } \\
\cline { 2 - 4 } & Total & Including to Germany & \% to Germany & 320,6267 \\
\hline 1930 & 333,739 & 199,925 & 59,9 & 335,2898 \\
\hline 1931 & 273,119 & 125,426 & 45,9 & 278,2442 \\
\hline 1932 & 189,126 & 74,018 & 39,1 & 249,6424 \\
\hline 1933 & 160,227 & 52,468 & 32,7 & 251,7602 \\
\hline 1934 & 147,245 & 31,819 & 21,6 & 276,8661 \\
\hline 1935 & 152,268 & 5,435 & 3,6 & 287,7211 \\
\hline 1936 & 190,485 & 20,599 & 10,8 & 318,153 \\
\hline 1937 & 208,325 & 34,479 & 16,6 & 366,4875 \\
\hline 1938 & 233,198 & 62,493 & 26,8 & \\
\hline
\end{tabular}

(Norkus, 2014; Statistical Bulletin, 1930-1939)

The loss of Klaipeda in March 1939 was another severe economic blow when Lithuania, by losing the region, also lost $150 \mathrm{mln}$. Litas, including $40 \mathrm{mln}$. Litas invested by the state in the economy. The problems also arose related to the housing of the evacuated institutions (Terleckas, 1992). Due to the loss of Klaipeda, the state income decreased by $38 \mathrm{mln}$ Litas, therefore, the budget was revised and reduced from 367,9 mln to 341,8 $\mathrm{mln}$ Litas. Moreover, trade problems were faced, as $70-80 \%$ of the Lithuanian foreign trade was carried out via the port of Klaipeda. When Vilnius was recovered in 1939, the country had to deal with social problems and to support the local population, therefore, the export of Lithuania decreased by $25 \mathrm{mln}$ Litas, and the budget expenses increased. On 23 October 1939, a forced emergency Vilnius loan of $50 \mathrm{mln}$ Litas was declared, and the state budget was again increased to $363,3 \mathrm{mln}$. Litas.

The economic life was disrupted by the onset of the Second World War in 1939. The Lithuanian export fell, it became difficult to get raw materials, and damage was caused by the seizure of Lithuanian ships by the fighting states and the requisitioning of goods. Thus, e.g., Lithuania lost 2,871,3 tons of fuel (kerosene, petrol, and gasoline) purchased in the USSR, as France detained a tanker following from Batumi to Riga in the Mediterranean. The British Goldez company refused to deliver the sugar purchased by Lithuania (Žepkaitė, 1990), and the new weaponry purchased abroad never reached the country (Jokubauskas, 2014). A shortage of raw materials raised fears that the protracted war might result in getting no goods or raw materials from abroad. Given the situation, the army received orders to efficiently use the recources and to extend the terms of article use as long as possible (Kariuomenès tiekimo, 1940). Due to international trade disorders, the Lithuanian food processing industry had no more tin in 1940 and could no longer produce tinned food for the army, therefore, the tinned food in the 
storehouses were to be kept as inviolable reserve, as the stock could no longer be supplemented (Kariuomenès tiekimo, 1940). The risk that in case of war Lithuania was not going to be reached by imported goods, and especially energy resources, i.e. fuel, was one of the reasons that prevented the army's motorisation.The motorised units would have been paralysed as they depended on imported fuels (Jokubauskas, 2015).

Due to the outbreak of the Second World War, Lithuania was faced with a refugee admission problem. In 1939-1940, it had to provide assistance to the interned Polish war refugees by maintaining them (altogether, over 40,000 individuals were admitted, including 14,000 military men and about 27,000 civilians; quite a few of them were in the Vilnius Region recovered in the autumn of 1939). The total of $8 \mathrm{mln}$ Litas were spent on that; the Lithuanian Government allocated 2, $54 \mathrm{mln}$ Litas, and the rest came from international organisations and foreign states) (Surgailis, 2005; Strelcovas, 2010). Thus, the refugees accounted for 1,5\% of the population of the country, and their maintenance cost about $0,7 \%$ of the state budget, apart from the funds received from organisations and the foreign aid.

In the interwar years, Lithuanian society experienced the problems of social exclusion and poverty. In 1940, Director of the State Security Department Augustinas Povilaitis emphasised, next to the social exclusion problem, also the issue of excessive alcohol consumption, as ,numbers of workers and their families suffered from poverty“ (Povilaitis, 1940). The press rebuked: „we loved to get closed in our offices, farms, or vegetable gardens and dawdle there, without looking around and worrying about our towns being poor and rickety, and our roads dirty and muddy"(I darbą, 1939). However, poverty and social exclusion were actualised in a broader context, i.e. that of the statehood preservation. In 1940, several months before the Soviet occupation, concerns were expressed about the impact of a lack of justice and poverty on the preservation of statehood:

„And finally, an important factor for the preservation of independence is the implementation of social justice all over the country, in other words, a fair distribution of wealth and earnings. If justice is said to be the basis of the state, the lack of clear justice in the social sphere in present times has a very, very negative impact on the general public. It is an indisputable fact that the greater part of wealth and capital today is in the hands of a few people. Social difference is less expressed in rural areas, however, in the urban ones it is felt quite keenly. Therefore, in this direction, clear, resolute, and just steps are to be made to have the wealth and earnings more fairly distributed between all the population of the country“ (Senkus, 1940).

The situation was very aptly defined in the Trimitas journal in 1939:

„When no gap is left between the rich and the poor, the overeating and the hungry, the idlers and the overwrought ones, and the educated and the ignorant, the homeland and all its children will feel good" (Markonis, 1939).

The problems of social inequality and exclusion were seen and publicly discussed, and they were considered to be important in the state security context.

\section{Conclusions:}

The revealed range of threats to the security and stability of the state of Lithuania led to the conclusion that, in the interwar period, Lithuania was faced with a number of indirect actions of unfriendly-minded countries, based on the weaknesses and problems of Lithuania, in addition to direct conventional military threats. Three blocks of action against the state of Lithuanian can be identified:

- Economic measures: economic warfare (embargo and sanctions) which resulted in the excerbation of the political, social, and economic national problems;

- Military operations: demonstration of the military power, the de jure-used non-state military formations or fighters trained in the neighbouring countries being sent over, and the use of paramilitary formations of the local residents, hostile to the state of Lithuania, for taking over the control or destabilisation;

- the ideological and informational impact on the society of Lithuania seeking to break its will for resistance and to form and maintain an underground network of agents of information. 
The economic sanctions of Germany did not seek to destroy Lithuanian economy; they were used as a measure of impact in the pursuit of their own goals in the Klaipeda Region. Therefore, that was an example of indirect action which both made Lithuania retreat in the case of the sentenced Social Nationalists in the Klaipeda Region and partially contributed to the outbreak of another additional phenomenon: the farmers' strike in the Suvalkija Region and its consequences in Lithuania. Germany and Poland, under the cover of paramilitary forces, uprisings of military units, or armies without states, pursued their political objectives through military means in order to avoid political consequences on the international arena and not to experience the sanctions or the pressure from the Western allies.

Agents of influence, underground organisations, and spies and distributors of rumours and disinformation sought by their activities to undermine public confidence in their own powers and in their state and competently used the weaknesses of the authoritarian regime for that purpose. On the one hand, an underground platform for a new political regime was developed; on the other hand, the public atmosphere of the transience of the state of Lithuania, its helplessness against the powerful neighbours, and therefore its unavoidable collapse was created.

The total range of the threats for the national security and statehood faced by Lithuania in the interwar period is not and, of course, can not be identical to the challenges of the second decade of the $21^{\text {st }}$ century, however, it boasts some clear and tangible parallels. Naturally, there is a number of aspects in which the restored Republic of Lithuania essentially differs from the interwar Republic of Lithuania. The key difference is the $21^{\text {st }}$ century Lithuania belonging to NATO, the most powerful global alliance of collective defence, and being a member state of the European Union, while in the interwar period, it did not have any real (mutually committed) military allies.

\section{References}

Antrosios péstininkų divizijos intendantui, 1940 m. gegužès 24 d. [To Comissary of the $2^{\text {nd }}$ Infantry Division, 24 May 1940]. Lietuvos Centrinis Valstybès Archyvas [Lithuanian Central State Archives] = LCVA, f. 518, ap. 1, b. 227: 18.

Aplinkraštis žąsų pirkimo reikalu, 1934 m. lapkričio 15 d. Nr. 391 [Curriculum on the Geese Purchase Affair No. 391 , 15 November 1934]. LCVA, f. 391, ap. 4, b. 1: 12.

Audènas, J. 1966. Paskutinis posédis [The Last Meeting]. New York: Romuva.

Ažubalis, A. et al. 2007. Karo pedagogika Lietuvoje (1918-1940 m.) [Military Pedagogy in Lithuania (in the years 1918-1940)]. Vilnius: Generolo Jono Žemaičio Lietuvos karo akademija. file://C:/Users/Samsung/Downloads/karo_pedagogika\%20(2).pdf

Bagdonas, M. 1940. Po pusès karo metų [After Six War Months]. Trimitas, vasario 29, Nr. 9 (1002): 207-208. http://www.epaveldas.lt/ vbspi/biRecord.do?biExemplarId=39317\&biRecordId=4059

Balkus, M. 2013. 1935-1936 m. Užnemunès ūkininkų streikas: propagandos ir viešosios nuomonès apžvalga [Farmers' Strike in Užnemunė Region (1935-1936): a Review of Propaganda and Public Opinion]. Lietuvos istorijos metraštis 2012, Nr. 1: $103-118$. http://talpykla.istorija.lt/bitstream/handle/99999/1065/LIM\%202012-1_103_118.pdf?sequence=1\&isAllowed=y

Blažytė-Baužienė, D.; Tamošaitis, M.; Truska, L. 2009. Lietuvos seimo istorija, XX-XXI a. pradžia [History of the Seimas of Lithuania, the $20^{\text {th }}$ to the $21^{\text {st }}$ Century]. Vilnius: baltos lankos.

Butkus, Z.; Černiauskas, N. 2015. Krizė keičia Lietuvą: 1931-1935 metų pokyčiai visuomenèje ir valstybėje [Crisis Changes Lithuania: Alterations of the Society and the State in 1931-1935]. Lietuvos istorijos studijos, t. 36: 69-87. http://www.zurnalai.vu.lt/lietuvosistorijos-studijos/article/view/9317/7165

Carr, E. H. 1999. Kas yra istorija? [What is History?]. Vilnius: Vaga.

Collingwood, R. G. 1946. The Idea of History. Oxford: Clarendon Press.

Černavičiūtè, S. 2013. Mirties bausmès taikymo praktika: 1935-1936 m. Suvalkijos ūkininkų streikas [Practice of the Death Penalty: 1935-1936 Farmers' Strike in Suvalkija]. Istorija: mokslo darbai, t. LXXXXII, Nr. 4: 22-30. http://www.istorijoszurnalas.lt/index. php?option $=$ com_content\&view $=$ article $\&$ id $=519 \&$ Itemid $=496$ 
Ir taikos metu kariaujama (1937-1940 m.) [Warfare in a Peacetime (1937-1940)]. LCVA, f. 514, ap. 1, b. $284:$ 14-23.

I darbą visa Lietuva [All Lithuania to Work]. Trimitas, 1939, rugpjūčio 24, Nr. 34 (975): 819. http://www.epaveldas.lt/vbspi/biRecord. do?biExemplarId=39419\&biRecordId=4059

Jokubauskas, V. 2013. Lietuvos karine doktrina ir jos realizavimas 1923-1940 m. Šiaurès rytu Baltijos regiono šaliu kontekste [The Lithuanian Military Doctrine and its Implementation in the Context of the Countries of the North-Eastern Baltic Region in the Period 1923-1940]. [Doctoral Dissertation]. Klaipeda: Klaipedos universiteto leidykla.

Jokubauskas, V. 2015. Lietuvos kariuomenès kavalerija tarpukariu: reguliarieji pulkai, šauliai dragūnai ir teritorinių dragūnų tarnyba [Lithuanian Army Cavalry During the Interwar Period: Regular Regiments, Shooters - Dragoons, and Territorial Dragoon Service]. Karo archyvas, t. XXX: 238-288. file:///C:/Users/Samsung/Downloads/karo\%20archyvasxxx\%20internetui\%20(5).pdf

Jokubauskas, V. 2016. Lietuvos kariuomenès išvedimas iš Klaipėdos krašto (1939 m.) [Withdrawal of the Lithuanian Army from Klaipeda Region (1939)]. Karo archyvas, t. XXXI: 232-273. file://C:/Users/Samsung/Downloads/karo\%20archyvas\%20xxxi\%20internetui\%20(1).pdf

Jokubauskas, V. 2014. „Mažujų kariuomeniu““ galia ir paramilitarizmas. Tarpukario Lietuvos atvejis [The Power of "Small Armies” and Paramilitarism: the Case of Interwar Lithuania]. Klaipèda: Klaipėdos universiteto leidykla.

Jokubavičienė, I. 2012. Dar kartą apie Ernesto Neumanno ir Teodoro Sasso procesą [Another Look at the trial of Ernst Neumann and Theodor Sass]. Darbai ir dienos, t. 57: 31-63. http://etalpykla.lituanistikadb.lt/fedora/get/LT-LDB-0001:J.04 2012 1367189203903/ DS.002.0.01.ARTIC

Kariuomenès štabo aplinkraštis, 1935 m. vasaris [General Staff Curriculum, February 1935]. LCVA, f. 929, ap. 1, b. 591: 22

Kariuomenès štabo II skyrius, 1935 m. rugsejjo 12 d. [2 $2^{\text {nd }}$ Division .of the General Staff, 12 September 1935]. LCVA, f. 929, ap. 1, b. $596: 35$.

Kariuomenès tiekimo valdybos aplinkraštis Nr. 4, 1940 m. birželio 8 d. [Army Supply Board Circular No. 4, 8 June 1940]. LCVA, f. 518, ap. 1, b. 197: 43 .

Kasparavičius, A. 1996. Didysis X Lietuvos užsienio politikoje [The Great X in Lithuanian Foreign Policy]. Vilnius: Lietuvos istorijos institutas.

Kasparavičius, A. 1999. Lietuvos kariuomenė Maskvos politinėse ir diplomatinėse spekuliacijose (1920-1936) [Lithuanian Army in Moscow ,s Political and Diplomatic Speculations]. In Lietuvos nepriklausomybei - 80. Straipsniu rinkinys. Vilnius: 4-57. file:///C:/Users/Samsung/Downloads/liet_nepriklausom_80.pdf

Kasparavičius, A. 2011. Katastrofos nuojautos: lietuvių karinė diplomatija Antrojo pasaulinio karo išvakarèse [Catastrophy Presentiments: Lithuanian Military Diplomacy on the Eve of the Second World War]. In Lietuvos karine diplomatija XXI amžiuje: retrospektyva ir perspektyva. Mokslinès praktinès konferencijos medžiaga. Vilnius, $2010 \mathrm{~m}$. gruodžio $3 \mathrm{~d}$. Vilnius: Generolo Jono Žemaičio Lietuvos karo akademija: 28-36. file://C:/Users/Samsung/Downloads/lietuvos\%20karine\%20diplomatija\%20xxi\%20amziuje_internetui\%20 (1).pdf

Kasparavičius, A. 2012. Katastrofos nuojautos: Lietuvos karinė diplomatija Antrojo pasaulinio karo išvakarèse [Catastrophe Presentiments: Lithuanian Military Diplomacy on theEve of the Second World War]. Karo archyvas, t. XXVII: 232-274. file://C:/Users/Samsung/Downloads/karo_archyvas_xxvii_internetui\%20(1).pdf

Klaipėdos nuotaikos [Moods in Klaipėda]. Vakarai, 1939 kovo 18, Nr. 65 (975): 10. http://www.epaveldas.lt/vbspi/biRecord. do?biExemplarId $=54734$

Kuodys, M. 2009. Karo padèties režimas Lietuvos Respublikoje 1919-1940 m. [Martial Law in the Republic in Lithuania in 1919 to 1940]. [Doctoral Dissertation]. Kaunas: Vytauto Didžiojo universitetas. http://vddb.library.lt/fedora/get/LT-eLABa-0001:E.02 2009 $\sim$ D_20091204_103200-29846/DS.005.0.01.ETD

Kuodys, M. 2013. Painūs „Lietuvos aido“ komentarai apie 1935 m. Suvalkijos ūkininkų streiko iniciatorius [Confusing Comments of 'Lietuvos aidas' about the Farmers' Strike in Suvalkija in 1935]. Istorija: mokslo darbai, t. LXXXXII, Nr. 4: 14-21. http://www.istorijoszurnalas.lt/index.php?option=com_content\&view=article\&id $=518 \&$ Itemid $=495$

Laurinavičius, Č. 2010. Ką reiškia Lietuvai turèti Klaipèdą? [What is the Significance of Klaipèda to Lithuania?] In Klaipédos krašto aneksija 1939 m.: politiniai, ideologiniai, socialiniai ir kariniai aspektai [The 1939 Annexation of Klaipeda Region: Political, Ideological, Social and Military Issues] (Acta Historica Universitatis Klaipedensis, t. XXI). Sud. S. Pocyte. Klaipeda: 11-31. http://briai.ku.lt/ downloads/AHUK_21/21_011-031_Laurinavicius.pdf 
Lesčius, V. 2004. Lietuvos kariuomene nepriklausomybès kovose 1918-1920 [Lithuanian Army in Liberation Wars 1918-1920]. Vilnius: Generolo Jono Žemaičio Lietuvos karo akademija. file:///C:/Users/Samsung/Downloads/lietuvos_kariuomene_1.pdf

Lesčius, V. 2013. Lietuvos kariuomenès gynybos planai ir priemonės galimai lenkų agresijai atremti 1921-1937 m. [Plans of Defence and Measures by Lithuanian Army to Repulse the Possible Polish Agression in 1921-1937]. Karo archyvas, t. XXVIII: 149-304. file:///C:/Users/Samsung/Downloads/karo_archyvas_xxviii+internetui+.pdf

Lietuva 1918-1938: leidinys 20 metu Lietuvos nepriklausomybès sukakčiai paminèti [Lithuania 1918-1938: to Commemorate the 20 th Anniversary of Lithuania 's Independence]. Red. V. Kemežys. 1990 [First Edition 1938]. Kaunas: Šviesa.

Lietuvos atstovybė Vokietijoje. 1933 m. gruodžio 2 d. [Lithuania‘s Embassy in Germany, 2 December 1933]. LCVA, f. 671, ap. 1, b. 7: 261.

Markonis, S. 1939. Geros valios talka [Good Will Assistance]. Trimitas, gruodžio 22, Nr. 51-52 (992-993): 1238-1239. http://www. epaveldas.lt/vbspi/biRecord.do?biExemplarId=39400\&biRecordId=4059

Marksas, K. 1949. Luji Bonaparto Briumerio aštuonioliktoji [The Eighteenth Brumaire of Louis Napoleon]. In Marksas, K.; Engelsas, F. Rinktiniai raštai [Selected Writings], t. I. Vilnius: Valstybinè politinès ir mokslinès literatūros leidykla.

Meindl, R. 2007. Ostpreußens Gauleiter. Erich Koch - eine politische Biographie [East Prussia Gauleiter. Erich Koch - A political biography]. Osnabrück: Fibre.

Meškauskas, K. et al. 1976. Lietuvos pramone ikisocialistiniu laikotarpiu [Lithuanian Industry in the Pre-Socialist Period]. Vilnius: Mintis.

Norkus, Z. 2014. Du nepriklausomybès dvidešimtmečiai. Kapitalizmas, klasès ir demokratija Pirmojoje ir Antrojoje Lietuvos Respublikoje lyginamosios istorinès sociologijos pažiūriu [Two Twenty-Year Periods of Independence: Capitalism, Class and Democracy in the First and Second Republics of Lithuania from the Point of View of Comparative Historical Sociology]. Vilnius: Aukso žuvys. http://web.vu.lt/fsf/z.norkus/files/2014/02/Du20me\%C4\%8Diai.pdf

Norkus, Z. 2015. Kas turtèjo greičiausiai? Baltijos šalių ūkio augimo 1913-1938 metais palyginimas [Who Enriched the Fastest? A comparison of the Economic Growth of Baltic Countries in 1913-1938]. Politologija, Nr. 3 (79): 3-54. http://www.zurnalai.vu.lt/ politologija/article/view/8428/6296

Norkus, Z. 2016. Apie pirmuosius nacionalinių pajamų skaičiavimus tarpukario Lietuvoje ir Albino Rimkos juose padarytas klaidas, pagreitinusias demokratijos žlugimą [On the First Calculations of National Income in the Interwar Lithuania and Albinas Rimka's Errors, which did Accelerate the Fall of Democracy]. Lietuvos istorijos studijos, t. 38: 42-71. http://www.zurnalai.vu.lt/lietuvos-istorijosstudijos/article/view/10389

Norkus, Z.; Morkevičius, V. 2011. Kokybinè lyginamoji analize [Qualitative Comparative Analysis]. Kaunas: Lietuvos HSM duomenų archyvas; Vilnius: Vaistų žinios.

Pirmasis karinès propagandos vakaras [The First Evening of Military Propaganda]. Karys, 1940, kovo 14, Nr. 11 (1091): 328. http://www.epaveldas.lt/vbspi/biRecord.do?biExemplarId=85433\&biRecordId=7942

Pocytè, S. 2002. Mažlietuviai Vokietijos imperijoje 1871-1914 [Prussian Lithuanians in the German Empire 1871-1914]. Vilnius: Vaga. Povilaitis, A. 1940. Alkoholis ir kova su juo [Alcohol and Fight against it]. Trimitas, kovo 21, Nr. 12 (1005): 281-282. http://www. epaveldas.lt/vbspi/biRecord.do?biExemplarId=39341\&biRecordId=4059

Pro Memoria. Dèl p. Zechlin audiencijos pas p. Respublikos Prezidentą, 1939 m. sausio 15 d. [On Mr. Zechlin's .Audience to Mr. President of the Republic, 15 January 1939]. LCVA, f. 671, ap. 1, b. 21: 31-31a.

Rezmer, W. 2004. Vidurio Lietuvos karinis potencialas [The Military Potencial of Central Lithuania]. Darbai ir dienos, t. 40: 79-88.

Safronovas, V. 2010. „Memelenderių“ daryba, arba ideologinis 1939 m. Klaipėdos krašto aneksijos parengimas [The Making of 'Memelländer': how the 1939 Klaipeda Region Annexation was Ideologically Prepared?]. In Klaipédos krašto aneksija 1939 m.: politiniai, ideologiniai, socialiniai ir kariniai aspektai [The 1939 Annexation of Klaipéda Region: Political, Ideological, Social and Military Issues] (Acta Historica Universitatis Klaipedensis, t. XXI). Sud. S. Pocytè. Klaipeda: 32-68. http://briai.ku.lt/downloads/ AHUK_21/21_032-068_Safronovas.pdf

Senkus, J. 1940. Lietuvos Nepriklausomybès išlaikymas [Preservation of Lithuania‘s Independence]. Kardas, vasario 15, Nr. 4 (328): 82-87. http://www.epaveldas.lt/vbspi/biRecord.do?biExemplarId=4203\&biRecordId=2338

Statistikos biuletenis (1930-1939) [Statistical Bulletin 1930-1939]. Kaunas: Finansų ministerija, Centrinis statistikos biuras. http://www.epaveldas.lt/vbspi/biSerial.do?biRecordId=4079 
Strelcovas, S. 2010. Antrojo pasaulinio karo pabègèliai Lietuvoje 1939-1940 metais [World War II Refugees in Lithuania (1939-1940)]. Šiauliai: Šiaulių universiteto leidykla.

Surgailis, G. 2005. Antrojo pasaulinio karo pabėgèliai ir internuotieji Lenkijos kariai Lietuvoje (1939 09-1940) [Second World War Refugees and the Interned Polish Military People in Lithuania (09 1939-1940)]. Vilnius: Generolo Jono Žemaičio Lietuvos karo akademija. file:///C:/Users/Samsung/Downloads/pabegeliai01_bandau.pdf

Šepetys, J. 1939. Dvasinis karas [Spiritual Warfare]. Karys, balandžio 20, Nr. 16 (1036): 493-495. http://www.epaveldas.lt/vbspi/biRecord.do?biExemplarId=85487\&biRecordId=7942

Šidlauskas, B. 1938. Atsargos karių pratimai [Army Researve Exercise]. Kardas, rugsèjo 1, Nr. 17 (295): 383-384. http://www.epaveldas.lt/vbspi/biRecord.do?biExemplarId=4248\&biRecordId=2338

Širvys, St. 1940. Neužsičiaupiančios lūpos [Non-Shutting Lips]. Karys, sausio 4, Nr. 1 (1081): 6-7. http://www.epaveldas.lt/vbspi/ biRecord.do?biExemplarId=85435\&biRecordId $=7942$

Šliogeris, V. 1996. Antanas Smetona: žmogus ir valstybininkas. Atsiminimai [Antanas Smetona: Man and Statesman]. Sodus, Mich.: Bachunas.

Taylor, R. 1990. Interpretation of the Correlation Coefficient: A Basic Review. Journal of diagnostic medical sonography, January / February, Vol. 6, No. 1: 35-39.

Tamošaitis, M. 2010. Didysis apakimas: lietuviu rašytojų kairejimas 4-ajame XX a. dešimtmetyje [Great Blindness: Leftism of Lithuanian Authors in the 30 s of the $20^{\text {th }}$ century]. Vilnius: Gimtasis žodis.

Tamošaitis, M.; Svarauskas, A. 2014. Nuo Kazio Griniaus iki Antano Smetonos. Valdžios ir opozicijos santykiai Lietuvoje $1926-1940$ metais [From Kazys Grinius to Antanas Smetona. Relations between Government and Opposition]. Vilnius: Gimtasis žodis.

Terleckas, V. 1992. Pinigai Lietuvoje 1915-1944 [Money in Lithuania in 1915 to 1944]. Vilnius: Lietuvos rašytojų s-gos leidykla.

Tosh, J. 2010. The Pursuit of History: Aims, methods and new directions in the study of modern history. Fifth Edition. Harlow: Pearson Education Ltd. https://www.scribd.com/doc/171550814/John-Tosh-In-the-Pursuit-of-History-eBook-Full

Truska, L. 1996. Antanas Smetona ir jo laikai [Antanas Smetona and his Times]. Vilnius: Valstybinis leidybos centras.

Vaičenonis, J. 2004. Lietuvos kariuomenè valstybes politinio gyvenimo verpetuose (1927-1940) [The Role of the Army in the Political Life of the First Republic of Lithuania (1927-1940)]. Vilnius: Versus Aurius.

Vareikis, V. 1995. Klaipėdos krašto užėmimas. In 1923 metų sausio ịvykiai Klaipėdoje (Acta Historica Universitatis Klaipedensis, t. IV). Klaipèda: $35-40$.

Vareikis, V. 1999. Lietuvos šaulių sajungos politine ir karinè veikla (1919-1923) [The Lithuanian Riflemen 's Union Political and Military Activity (1919-1923)]. [Doctoral Dissertation]. Kaunas: Vytauto Didžiojo universitetas.

Vareikis, V. 2004. Pasienio incidentai (Lietuvos šaulių partizaninè veikla) [Border incidents (The Partisan Activities of Lithuania's Šauliai]. Darbai ir dienos, t. 40: 109-128.

Vareikis, V. 2009. Dèl „lango ị platujj pasaulį“: Lietuvos šaulių sajunga 1923 metų Klaipedos sukilimo metu [On the „Window into the Wide World“": the Lithuanian Riflemen's Union during the Klaipeda Uprising 1923]. In Lietuvos šauliu sajunga: praeitis, dabartis, ateitis. Leidinys skirtas Lietuvos šauliu sajungos gyvavimo 90-mečiui. Sud. R. Varsackytè. Kaunas: 57-76.

Vareikis, V. 2009a. Klaipèdos krašto praradimas: tarp iliuzijų ir Realpolitik [The Loss of the Klaipėda Region: between Illusion and Realpolitik]. Kultūros barai, 2009, Nr. 3 (532): 68-75. https://docs.google.com/viewer?url=http://www.kulturosbarai.lt/uploads/news/ id27/KB_2009_3_pdf.pdf

Vaskela, G. 1998. Žemès reforma Lietuvoje 1919-1940. Analizuojant Rytu ir Vidurio Europos agrarinès raidos XXa. III-IV dešimtmečiais tendencijas [The Land Reform in Lithuania of 1919-1940. Analysing trends of agrarian development in East and Central Europe in $30^{\text {th }}-40^{\text {th }}$ years $20^{\text {th }}$ century]. Vilnius: Lietuvos istorijos instituto leidykla.

Vaskela, G. 2002. Lietuva 1939-1940 metais. Kursas i valstybès reguliuojama ekonomika [The Course towards State-Regulated Economy in Lithuania in 1939-1940]. Vilnius: Lietuvos istorijos instituto leidykla.

Vileišis, V. 1935. Tautiniai santykiai Mažojoje Lietuvoje ligi Didžiojo karo. Istorijos ir statistikos šviesoje su 3 žemèlapiais [National Relations in Lithuania Minor before the Second World War. In the Light of History and Statistics with 3 maps]. Kaunas: Politinių ir socialinių mokslų instituto leidinys. 
Vilkelis, G. 2006. Lietuvos ir Lenkijos santykiai Tautu Sajungoje [The Rrelations between Lithuania and Poland at the League of Nations]. Vilnius: Versus Aurius.

Vokietijos karinè veikla, 1940 gegužès 1 d. [Germany‘s Military Activities, 1 May 1940]. LCVA, ap. 2, b. $1084: 16$.

Žalys, V. 1993. Kova dèl identiteto. Kodèl Lietuvai nesiseké Klaipédoje tarp 1923-1939 m. [Fight for Identity. Why did Lithuania Fail in Klaipeda between 1923-1939]. Lüneburg: Nordostdeutsches Kulturwerk.

Žalys, V. 2007. Lietuvos diplomatijos istorija (1925-1940) [History of Lithuania 's Diplomacy (1925-1940)], t. I. Vilnius: Versus Aurius.

Žepkaitè, R. 1990. Vilniaus istorijos atkarpa 1939-1940 [A Section of Vilnius History 1939-1940]. Vilnius: Mokslas.

Žostautaitè, P. 1992. Klaipèdos kraštas 1923-1939 [The Klaipėda Region 1923-1939]. Vilnius: Mokslas.

Žukas, J. 2010. Klaipėdos krašto ekonominè raida XIX a. antroje pusejje - XX a. pirmoje pusėje (1871-1939 m.) [Economic Development of the Klaipeda Region in the late $19^{\text {th }}-$ early $20^{\text {th }}$ Century]. [Doctoral Dissertation]. Klaipèda: Klaipedos universiteto leidykla.

Мельтюхов, М. 2014. Прибалтийский плащдарм (1939-1940). Возращение Советского Союза на берега Балтийского моря [Тһе Baltic Bridgehead (1939-1940). Return of the USSR to the Baltic Seacoast]. Москва: Алгоритм. 